\title{
Detection of Apple Stem Grooving Virus in Dormant Apple Trees with Crude Extracts as Templates for One-Step RT-PCR
}

Vera L. A. Marinho, J. Kummert, G. Rufflard, D. Colinet, and P. Lepoivre, Unité de Phytopathologie; Faculté Universitaire des Sciences Agronomiques, 2, Passage des Déportés; Gembloux; Belgium

\begin{abstract}
Marinho, V. L. A., Kummert, J., Rufflard, G., Colinet, D., and Lepoivre, P. 1998. Detection of apple stem grooving virus in dormant apple trees with crude extracts as templates for one-step RT-PCR. Plant Dis. 82:785-790.

Partial nucleotide sequences of amplification products obtained from four European apple stem grooving virus (ASGV) isolates using degenerate primers showed 80 to $85 \%$ similarity with the published ASGV sequence of a Japanese strain but 98 to $100 \%$ identities among themselves. Based on these sequences, two ASGV-specific primers (ASGV4F-ASGV4R) were designed to amplify a 574-bp fragment located in the putative viral RNA polymerase. With these primers, six European and five American ASGV isolates, maintained in herbaceous hosts (Chenopodium quinoa, Nicotiana glutinosa, and N. occidentalis) or in apple trees, were readily detected by reverse transcription-polymerase chain reaction (RT-PCR). Using these specific ASGV primers, dsRNA preparations have been shown to constitute good templates for reliable amplification of ASGV sequences from leaves and bark tissues of apple trees, both in a two-step RT-PCR protocol and in the one-step Titan One-Tube RT-PCR. System. Furthermore, the one-step RT-PCR system allowed a specific amplification of ASGV sequences directly from clarified crude extracts of leaves and bark tissues of apple trees during both active growth and the dormant season.
\end{abstract}

Apple stem grooving virus (ASGV), apple chlorotic leafspot virus (ACLSV), and apple stem pitting virus (ASPV) are latent viruses with elongated flexuous particles that infect pome fruit trees. ASGV is the type member of the capillovirus genus (1). The virions are morphologically similar to the newly established genus Trichovirus, of which ACLSV is the type member. ASGV is distributed worldwide in apple (10), but it also infects pear, apricot (15), and cherry trees (7). This virus contains a polyadenylated, plus sense, single-stranded RNA of 6,496 nucleotides (26). The ASGV genome has two overlapping open reading frames (ORFs) encoding a $241-\mathrm{kDa}$ polyprotein and a $36-\mathrm{kDa}$ protein (26). The $241 \mathrm{kDa}$ polyprotein contains the conserved motifs of a helicase, an RNA polymerase, and the coat protein coding region. Other members of the capillovirus group are cherry virus A (CVA) (6) and citrus tatter leaf virus (CTLV). However, recent data suggest that CTLV should be regarded as a closely related strain of ASGV rather than a different virus $(12,16)$. relies on grafting of budwood on Malus sylvestris cv. Virginia Crab, which devel-

Corresponding author: J. Kummert

E-mail: phytopat@fsagx.ac.be

Accepted for publication 14 April 1998.

Publication no. D-1998-0513-01R

(C) 1998 The American Phytopathological Society
Biological indexing of ASGV usually ops long grooves on the woody stem (23). Although the use of newly described Malus clones allows ASGV detection within 2 months (5), biological indexing remains lengthy. Moreover, it is not specific and may not differentiate among related viruses in mixed infections.

Serological detection by enzyme-linked immunosorbent assay (ELISA) using commercially available antisera represents the first alternative for biological indexing, but its use is limited to a short time period in the growing season and appears inappropriate with dormant woody tissues $(7,8,11)$.

Molecular hybridization-based techniques represent additional alternatives for biological indexing. ASGV detection methods based on reverse transcription-polymerase chain reaction (RT-PCR) have been re- ported by Kummert et al. (8) using degenerate primers designed from conserved sequences of the putative viral RNA polymerase. Recently, Kinard et al. (7) and MacKenzie et al. (11) reported RT-PCR detection of ASGV from apple tissues using specific primers targeting the putative coat protein encoding region of the viral genome. These protocols rely on two-step RT-PCR procedures using reverse transcriptase with oligo(dT) primer for first strand cDNA synthesis, and Taq DNA polymerase with ASGV-specific primers for PCR amplification. Recently, one-step RTPCR systems have been developed $(13,14)$, allowing both reactions (reverse transcription and DNA amplification) to be conducted in the same tube without any addition of primers or enzymes between the RT and the amplification steps, thus reducing the handling steps and the risks of contamination.

A critical step for routine use of PCR technology is template isolation. The standard sample extraction procedure for RTPCR detection of ASGV is based on nucleic acid isolation (total RNA) $(7,8,11)$, which is time-consuming and not amenable for processing large numbers of samples. Potentially improved sample processing procedures for plant virus detection by PCR have been reported and include immunocapture (24), direct binding (19), print capture (17), or direct application of clarified plant extracts in reaction tubes (25).

This paper reports the design of specific primers based on the comparison of partial nucleotide sequences established for four European ASGV isolates and that of the Japanese isolate published by Yoshikawa et al. (26). Using these specific primers and
Table 1. Apple stem grooving virus (ASGV) isolates

\begin{tabular}{|c|c|c|}
\hline Isolates & Present hosts & Origin \\
\hline 10311 & Herbaceous $^{\text {a }}$ (greenhouse) & Belgium \\
\hline 10391 & Herbaceous $^{\mathrm{a}}$ (greenhouse) & Belgium \\
\hline 10771 & Herbaceous $^{\text {a }}$ (greenhouse) & Belgium \\
\hline 10291 & Malus sp. cv. Golden (field tree) & Belgium \\
\hline 10392 & Malus sp. cv. Golden (field tree) & Belgium \\
\hline TH 1387 & Malus sp. (field tree) & Switzerland \\
\hline 111-7 & Malus sp. cv. Jonee (budwood) & United States \\
\hline $121-13$ & Malus sp. cv. Granny Smith (budwood) & United States \\
\hline $121-15$ & Malus sp. cv. Starking (budwood) & United States \\
\hline $123-18$ & Malus sp. cv. Granny Smith (budwood) & United States \\
\hline $111-3$ & Pyrus sp. cv. Twentieth Century (budwood) & United States \\
\hline
\end{tabular}

${ }^{a}$ Herbaceous hosts: Chenopodium quinoa, Nicotiana glutinosa, and N. occidentalis. ASGV isolates from Belgium and Switzerland were kindly supplied by P. Simon (Research Station of Gorsem, Belgium) and those from United States by W. E. Howell (Washington State University, Prosser). 

crude extracts prepared from dormant woody tissues, the one-step RT-PCR procedure is compared with a classical twostep protocol.

\section{MATERIAL AND METHODS}

Virus isolates and host plants. The ASGV isolates used in this study are listed in Table 1. European isolates 10311, 10391 , and 10771 were transferred by meChenopodium quinoa, Nicotiana glutinosa, and $N$. occidentalis. European isolates 10291, 10392, and TH 1387 were maintained in apple trees in the field. Budwood infected by the American isolates (111-7, 121-13, 121-15, 123-18, and 111-3) were different templates, including clarified chanical inoculation and multiplied in

maintained at $4^{\circ} \mathrm{C}$. Isolates of ACLSV (91300) and ASPV (91325) maintained in C. quinoa and in apple tree in the field, respectively, were occasionally used as control.

Primers. Degenerate (ACG1a and ACG2a) and virus-specific primers (ASGV4F and ASGV4R) (Table 2) were used for the amplification of viral sequences from infected herbaceous hosts or apple trees.

Template preparation. Total RNA was extracted from $0.1 \mathrm{~g}$ of leaf tissues of herbaceous plants and from $0.2 \mathrm{~g}$ of leaf and bark tissues of apple using TriPure Isolation Reagent (Boehringer Mannheim, Germany) according to the manufacturer's instructions.

Table 2. Nucleotide sequences of primers used for apple stem grooving virus (ASGV) detection

\begin{tabular}{|c|c|c|}
\hline Primer & Nucleotide sequence ( $5^{\prime}$ to $3^{\prime}$ ) & Expected size of amplicon \\
\hline ACG1 $\mathrm{a}^{\mathrm{a}}$ & ${ }^{3874}$ gtcgaaTTCCTNTTYATGAARTC 3890 & 639 bp \\
\hline $\mathrm{ACG} 2 \mathrm{a}^{\mathrm{a}}$ & ${ }^{4512}$ ctaggatCCANCCRCAAAACAT 4498 & \\
\hline ASGV4Fb & ${ }^{3918}$ GTTCACTGAGGCAAAAGCTGGTC ${ }^{3940}$ & $574 \mathrm{bp}$ \\
\hline ASGV4R ${ }^{\mathrm{b}}$ & ${ }^{4491}$ CTTCCGTACCTCTTCCACAGCAG ${ }^{4469}$ & \\
\hline
\end{tabular}

a Primers designed on consensus sequences found at the amino acid level in the RNA polymerase of apple chlorotic leafspot virus (ACLSV), ASGV, and apple stem pitting virus (ASPV) (8). The lower case letters represent $E c o$ RI or BamHI restriction sites introduced to facilitate the cloning of the PCR products.

${ }^{b}$ Primers designed on the basis of the nucleotide sequences of ASGV genome, isolate P-209 (26), and partial ASGV sequences of European isolates; numbers at termini indicate nucleotide positions in ASGV genome (P-209).

Table 3. Pairwise percent nucleotide sequence identities between the amplified fragments obtained with degenerate primers ACG1a-ACG2a for different apple stem grooving virus (ASGV) isolates

\begin{tabular}{lccccc}
\hline & P-209a $^{\mathbf{a}}$ & $\mathbf{1 0 7 7 1}$ & $\mathbf{1 0 3 1 1}$ & $\mathbf{1 0 3 9 1}$ & $\mathbf{1 0 3 9 2}$ \\
\hline P-209 & $\ldots$ & $85.3 \%(237)^{\mathrm{b}}$ & $85.2 \%(297)$ & $84.6 \%(298)$ & $86.6 \%(261)$ \\
10771 & & $\ldots$ & $99.6 \%(237)$ & $100 \%(237)$ & $100 \%(237)$ \\
10311 & & & $\ldots$ & $99.3 \%(297)$ & $99.6 \%(261)$ \\
10391 & & & & $\ldots$ & $99.6 \%(261)$ \\
10392 & & & & & $\ldots$ \\
\hline
\end{tabular}

a Reference isolate for which the sequence was published by Yoshikawa et al. (26).

${ }^{\mathrm{b}}$ In parentheses, size of nucleotide sequence analyzed.
Preparations of dsRNA were initially obtained from $20 \mathrm{~g}$ of leaf or bark tissues from apple trees according to the method of Valverde et al. (22). This method was later used with 0.5 to $1 \mathrm{~g}$ of plant material with affinity column chromatography through $200 \mathrm{mg}$ of $\mathrm{CF}-11$ cellulose contained in pipette tips. After ethanol precipitation, the final dsRNA pellets were resuspended in $10 \mu \mathrm{l}$ of diethylpyrocarbonate (DEPC)-treated water.

Crude plant extracts preparation was based on the method of Wyatt and Brown (25) with minor modifications. Plant tissues consisting of $50 \mathrm{mg}$ of leaves or bark scrapings from current-year apple tree shoots were ground in $1.0 \mathrm{ml}$ of TE buffer (50 mM Tris, pH 8.0, $10 \mathrm{mM}$ EDTA) and centrifuged at $10,000 \times g$ for $10 \mathrm{~min}$ at $4^{\circ} \mathrm{C}$. One microliter of the supernatant was transferred to another tube containing the RT-PCR mixture. Dilutions were made when appropriate using TE buffer.

In an additional procedure, referred to as tube binding, $50 \mu \mathrm{l}$ of the extracts clarified as described above were incubated in polypropylen PCR tubes for $30 \mathrm{~min}$ at $4^{\circ} \mathrm{C}$. The tubes were washed three times with $200 \mu \mathrm{l}$ of TE buffer before adding RT-PCR mixture (see below).

RT-PCR procedures. Two-step $R T$ $P C R$. Synthesis of cDNA was made using $1 \mu \mathrm{l}$ of purified dsRNA preparation corresponding to extracts from $0.1 \mathrm{~g}$ of plant tissue, or from 1 to $2 \mu \mathrm{g}$ of total RNA prepared from plant tissues. The Expand Reverse Transcriptase System (Boehringer) was employed according to manufacturer's protocol using oligo $\left(\mathrm{dT}_{15}\right)$ primer. Amplification was then performed with $5 \mu$ of cDNA in a $50-\mu \mathrm{l}$ mixture containing $5 \mu \mathrm{l}$ of 10× Taq buffer (100 mM Tris-HCl, $15 \mathrm{mM}$ $\left.\mathrm{MgCl}_{2}, 500 \mathrm{mM} \mathrm{KCl}, \mathrm{pH} 8.3\right), 200 \mathrm{mM}$ each of dATP, dCTP, dGTP, and dTTP, 1 unit of Taq DNA polymerase (Boehringer),

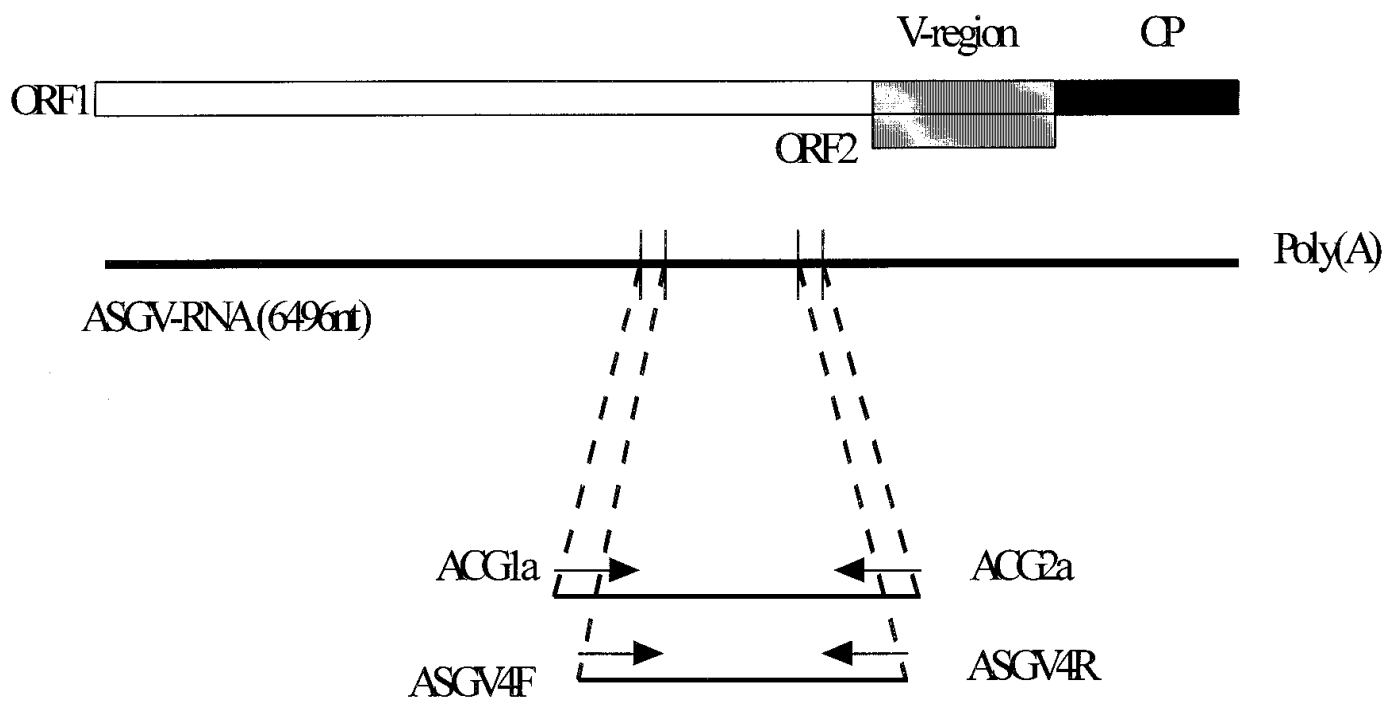

Fig. 1. Apple stem grooving virus (ASGV) genome map, according to Magome et al. (12), showing the location of degenerate primers (ACG1a-ACG2a) and specific primers $(\mathrm{ASGV} 4 \mathrm{~F}-\mathrm{ASGV} 4 \mathrm{R})$ used in this study. V-region = variable region in the polymerase gene $(12)$; $\mathrm{CP}=\mathrm{coat}$ protein region; ORF1,2 = open reading frames 1 and 2 ; nt $=$ nucleotides. 
and $1 \mu \mathrm{l}$ of each primer $(20 \mu \mathrm{M})$. The following thermal cycling scheme was used for 35 reaction cycles (Trio-Thermoblock cycler, Biometra Gmbh, Germany): template denaturation at $94^{\circ} \mathrm{C}$ for $30 \mathrm{~s}$, primer annealing at $62^{\circ} \mathrm{C}$ for $1 \mathrm{~min}$, and DNA synthesis at $72^{\circ} \mathrm{C}$ for $2 \mathrm{~min}$. Amplified fragments were visualized after electrophoresis in ethidium bromide stained $1 \%$ agarose gels.

One-step RT-PCR. The Titan One-Tube RT-PCR System was used according to manufacturer's protocols (Boehringer). In each reaction, $1 \mu \mathrm{l}$ of each primer $(20 \mu \mathrm{M})$ and $1 \mu \mathrm{l}$ of template (crude extracts, total RNA or dsRNA) were used. The reverse transcription step was performed at $50^{\circ} \mathrm{C}$ for $30 \mathrm{~min}$. Thermal cycling was performed as described for the two-step procedure.

DNA cloning and nucleotide sequence analysis. Amplified DNA fragments obtained with the degenerate primers ACG1a and ACG2a for the ASGV isolates 10311, 10391, 10771, and 10392 were recovered by the QIAEX gel extraction kit (Qiagen $\mathrm{GmbH}$, Germany). Purified DNA fragments were cloned in the pCR II vector, using the TA cloning kit (Invitrogen, Netherlands) following the manufacturer's instructions. Recombinant plasmids were monitored for appropriate size inserts by cleavages with $B a m \mathrm{HI}$ and $\mathrm{XhoI}$ restriction enzymes. Three independent clones from each ASGV isolate were sequenced by the dideoxyribonucleotide chain termination method of Sanger et al. (21), performed with T7 DNA polymerase (Pharmacia

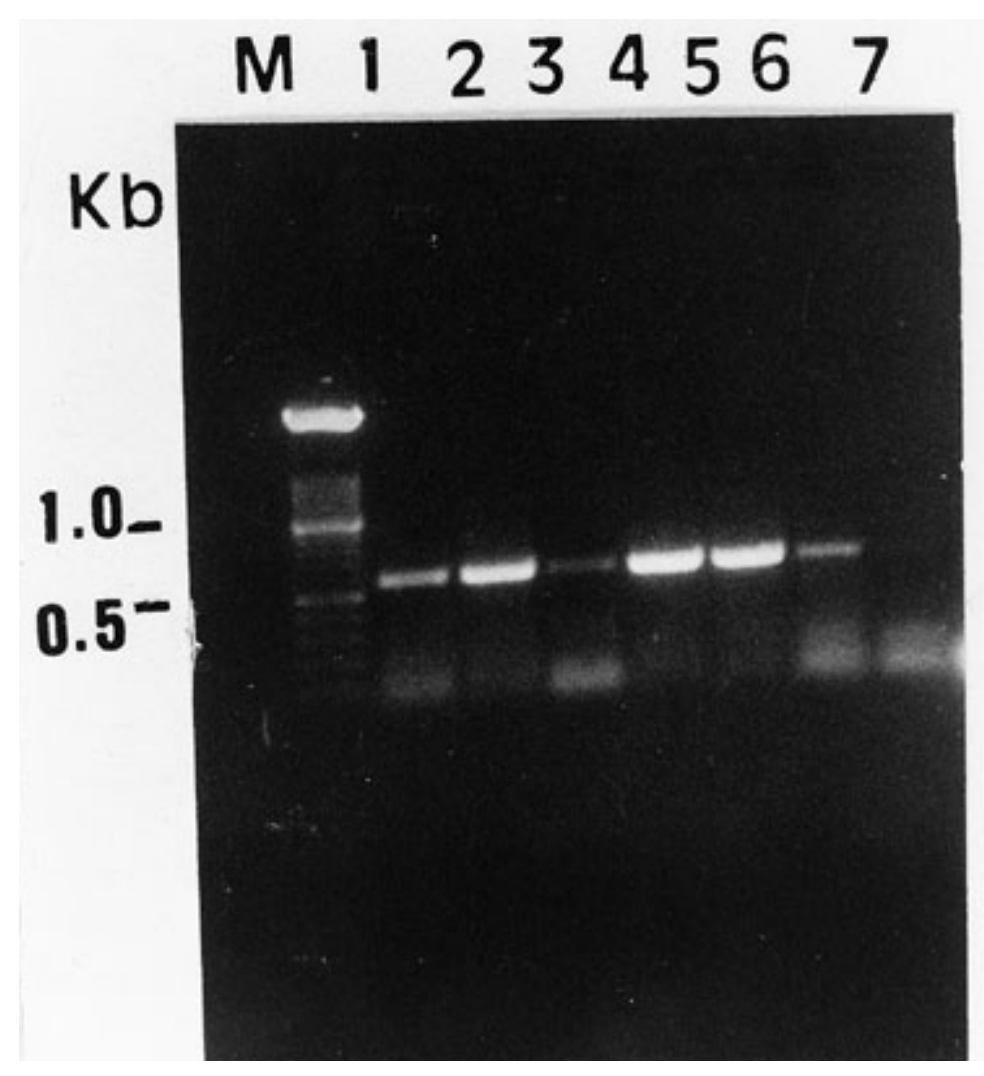

Fig. 3. Agarose gel electrophoretic analysis of one-step reverse transcription-polymerase chain reaction (RT-PCR) amplification products, obtained with the specific primers (ASGV4FASGV4R) from dsRNA preparations of budwood (dormant shoots) received from the United States (lanes 1, 2, 3, 4, 5 are isolates 112-15, 121-13, 111-3, 111-7, 123-18, respectively) or Chenopodium quinoa leaves infected with apple stem grooving virus (ASGV) isolate 10771 (lane 6). Blank (no template added) (lane 7). Molecular weight marker (100 bp DNA ladder, lane M).

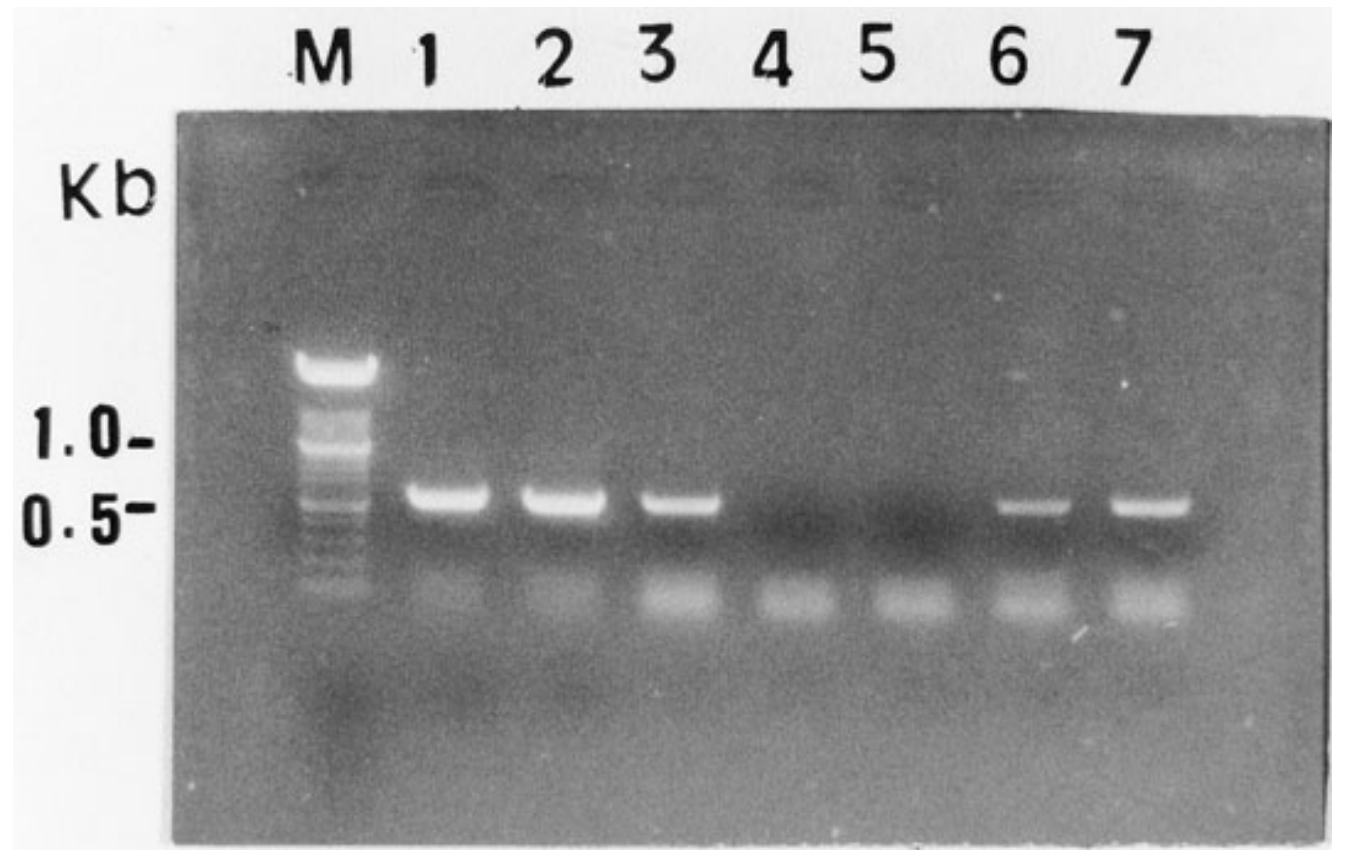

Fig. 2. Agarose gel electrophoretic analysis of reverse transcription-polymerase chain reaction (RT-PCR) amplification products, obtained with primers ASGV4F-ASGV4R from total RNA preparation of: Chenopodium quinoa leaves infected with apple stem grooving virus (ASGV) isolate 10311 (lane 1), Nicotiana glutinosa leaves infected with ASGV isolate 10391 (lane 2), apple tree leaves infected with ASGV isolate 10291 (lane 3), C. quinoa leaves infected with an apple chlorotic leafspot virus (ACLSV) isolate (lane 4), and C. quinoa healthy leaves (lane 5), or from dsRNA preparations of $C$. quinoa leaves infected with ASGV isolate 10771 (lane 6) and bark tissues of apple tree infected with ASGV isolate 10291 (lane 7). Molecular weight marker (100 bp DNA ladder, lane M). 
Biotech, Sweden) according to the manufacturer's instructions. Similarity analyses of nucleotide sequences were conducted with the DNASIS and University of Wisconsin Genetic Computer Group (GCG) sequence analysis software package version 8.0 (4).

\section{RESULTS}

Design of specific primers for the detection of ASGV. Reverse transcription with oligo(dT) primer followed by amplification with degenerate primers ACG1a and ACG2a (8) was performed on total RNA preparations from ASGV-infected herbaceous hosts (isolates 10311, 10391, 10771) and on one dsRNA preparation from an ASGV-infected apple tree (isolate 10392). The amplification products of the ASGV European isolates were cloned and sequenced. Sequence alignments revealed 98 to $100 \%$ identities among these four European isolates, and 80 to $85 \%$ identities with the published sequence of ASGV isolate P-209 (26) (Table 3). The specific primers ASGV4F-ASGV4R, giving rise to an expected amplified product of $574 \mathrm{bp}$, have been selected within conserved regions observed from the alignment of the partial sequences obtained for isolates 1311, 10391, 10392, and 10771. Figure 1 shows the localization of the degenerate and specific primers in the putative viral RNA polymerase (ORF1) of the ASGV genome.

Virus-specific RT-PCR detection. Two-step procedure. The specific primers were first assayed in a two-step RT-PCR protocol by using Expand Reverse Transcriptase with oligo(dT) primer for firststrand cDNA synthesis and Taq DNA po- lymerase for PCR amplification. RT-PCR was performed with total RNA prepared from ASGV-infected herbaceous host plants (isolates 10311 and 10391), and from ASGV-infected apple tree (isolate 10291). An amplification product with the predicted size of 574 bases was reliably obtained with extracts from ASGVinfected herbaceous plants and leaves of the ASGV-infected tree (Fig. 2, lanes 1 to 3). On several occasions, the specificity of the amplicons has been controlled by Southern blotting using a specific cloned DNA probe for ASGV isolate 10311 and corresponding to nucleotides 3,925 to 4,485 of ASGV RNA (results not shown). No amplification product was detected by ethidium bromide staining with total RNA prepared from bark of ASGV-infected tree (result not shown) or from the ACLSVinfected control and the healthy material (Fig. 2, lanes 4 and 5).

Correctly sized amplicons were observed with dsRNA preparations from ASGVinfected leaves of $C$. quinoa (isolate 10771) and from bark of ASGV-infected apple tree (isolate 10291) (Fig. 2, lanes 6 and 7).

One-step procedure. The Titan OneTube RT-PCR System was evaluated with the ASGV-specific primers ASGV4F and ASGV4R. With this procedure, experiments conducted during the entire year on leaves and bark tissues of two infected trees (isolates 10291 and 10392) showed that dsRNA preparations constituted good templates for RT-PCR detection of ASGV in apple trees, whereas total RNA preparations from bark obtained with TriPure Isolation Reagent provide no visible amplified products. Figure 3 shows the results ob- tained with budwoods of dormant shoots received from W. E. Howell (Washington State University, Prosser)

Since the isolation of dsRNA remains tedious for routine tests, the possibility of using one-step RT-PCR on crude extracts was considered. Both methods of crude extract utilization (direct incorporation in the PCR mix and binding of crude sap on the wall of the PCR tubes) yielded one correctly sized amplification product for all ASGV-infected samples from leaves of herbaceous hosts and leaves and bark tissues of apple trees. These were previously shown to be positive in RT-PCR tests performed on dsRNA preparations. The sensitivity of the protocol allowed virus detection from $1 \mu \mathrm{l}$ of a 1:2,000 dilution of clarified extracts obtained from $50 \mathrm{mg}$ of bark tissues from dormant shoots (Fig. 4).

\section{DISCUSSION}

Although ASGV, ACLSV, and ASPV belong to different virus genera, comparison of published amino acid sequences of their putative RNA polymerase allowed the selection of consensus sequences for the design of degenerate primers (8). This approach has been shown of practical use to detect most or all isolates of one particular virus or different related viruses within a genus, as shown for potyviruses $(2,9)$, luteoviruses $(18)$, or geminiviruses (20).

The degenerate primers for ASGV allow the cloning and sequencing of the amplification products obtained for four European ASGV isolates (Table 3), which indicates that these isolates are closely related. It allowed the design of ASGV-specific primers (ASGV4F-ASGV4R) located in

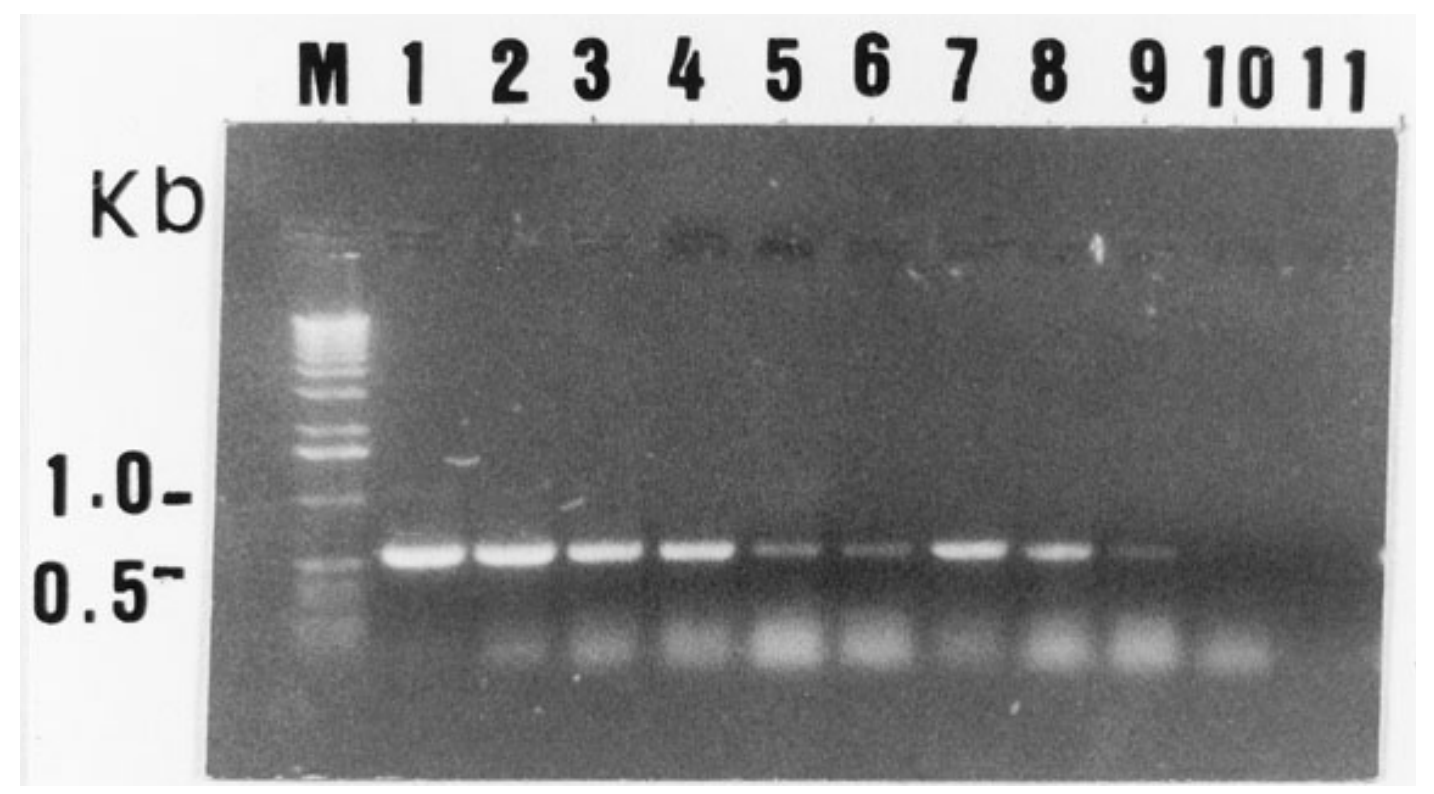

Fig. 4. Agarose gel electrophoretic analysis of one-step reverse transcription-polymerase chain reaction (RT-PCR) amplification products obtained with specific primers (ASGV4F-ASGV4R) from direct deposit of clarified plant extracts in the PCR mixture (1:20 dilution: lanes 1, 4, 7; 1:200 dilution: lanes 2, 5, 8; 1:2,000 dilution: lanes 3, 6, 9). Extracts of apple stem grooving virus (ASGV) isolate 10771 infected Nicotiana glutinosa (lanes 1 to 3) and ASGV isolate 10392 infected leaves (lanes 4 to 6) or bark tissue (lanes 7 to 9) of apple tree; healthy apple tree leaves (lane 10; dilution 1:200), and blank (lane 11). DNA size markers are shown in lane $\mathrm{M}$ (1 kb ladder size marker). 
the putative viral RNA polymerase. These specific primers correspond to conserved sequences of the four European isolates but contain five and four mismatches, respectively, with the sequence published for the Japanese isolate (26).

The occurrence of variable region (V-region) in the ORF1 encoded protein corresponding to the $3^{\prime}$ end of the putative ASGV RNA-polymerase was recently reported (12). The conserved sequence targeted by our primers is located about 300 nucleotides downstream from the Vregion (Fig. 1), allowing the detection of different European and North American ASGV isolates (Fig. 3).

With the specific ASGV primers, dsRNA preparations from leaves and bark tissues of apple trees were shown to be good templates for reliable amplification of ASGV sequences using two-step RT-PCR. In the same conditions, total RNA prepared from bark tissues and clarified crude extracts (result not shown) did not yield any detectable amplified product. When performed on dsRNA preparations, our RTPCR protocol overcame a significant limitation of ELISA on extracts from dormant woody tissues.

The use of the one-step Titan RT-PCR System is an alternative to the classical two-step system. The one-step system uses AMV reverse transcriptase for first-strand synthesis and the Expand high fidelity enzyme blend, which consists of a mixture of Taq DNA polymerase and Pwo DNA polymerase, for the DNA amplification (13). This technique is designed for the sensitive, quick, and reproducible amplification from RNA in a single optimized RTPCR buffer, with high fidelity and decreased error rates compared with the other one-step procedure using Tth DNA polymerase $(13,14)$. Using primers ASGV4FASGV4R, the Titan RT-PCR system allowed specific amplification of ASGV sequences directly from clarified crude plant extracts from leaves and bark tissues of apple trees that were shown positive in previous or comparable tests (either the one- or the two-step RT-PCR systems performed on dsRNA preparations). The onestep PCR protocol circumvents the usual requirement of nucleic acid isolation prior to PCR and is effective for detecting ASGV from bark samples of current-season dormant apple shoots. Crude plant extracts can be readily prepared, and the usual inhibitory effects of plant polysaccharides or other components of crude plant extracts on PCR amplification (3) were avoided by appropriate dilutions. We have no information on the nature of the viral material targeted (i.e., naked RNA or dsRNA).

Kinard et al. (7) and MacKenzie et al. (11) also reported the detection of ASGV, especially from bark and leaves of apple trees, by RT-PCR. Both used total RNA preparations as template in a classical two- step system. MacKenzie et al. also reported the detection in dormant wood, but the method used for extraction of the total RNA preparation is laborious and expensive for application on large numbers of samples.

Primer pairs designed by these authors were evaluated (both in our conditions and with the thermal cycles defined by the respective authors) with the Titan OneTube RT-PCR System in the presence of crude extracts from either ASGV-infected herbaceous host (isolate 10391) or apple tree (isolate 10392). Amplification products of expected size were visualized in ethidium bromide-stained agarose gels when using the primers of MacKenzie, but not those of Kinard (results not shown). The different results obtained using the respective primer pairs could be explained by their intrinsic characteristics, such as length, secondary structure, or Tm.

Control of virus diseases in woody plants depends on the detection and elimination of the agents through certification and clean-stock programs. Our experiments have shown that crude extracts from dormant apple tree tissues are good templates for reliable ASGV detection if combined with the Titan RT-PCR System and specific primers such as ASGV4FASGV4R. The ability to detect ASGV during both active growth and the dormant season will provide a valuable tool for certification programs. This procedure can also be incorporated into testing protocols during post-entry quarantines for rapid initial screening of imported budwood, or in virus eradication programs.

\section{ACKNOWLEDGMENTS}

We thank the Ministry of Agriculture of Belgium, which supported the present research through the "Convention D 1/4-6091/5698 A", and we thank P. Simon (Gorsem, Belgium) and W. E. Howell (Washington State University, Prosser) for providing samples of virus-infected material and virus isolates. The first author also thanks EMBRAPA (Brazilian Enterprise for Agricultural Research), which founded her doctoral fellowship, and J. Daniels for helpful suggestions and critical discussion.

\section{LITERATURE CITED}

1. Bar-Joseph, M., and Martelli, G. P. 1991. Capilloviruses. Page 339-340 in: Classification and Nomenclature of Viruses: 5th Report of the International Committee on Taxonomy of Viruses. Arch. Virol. Suppl. 2.

2. Colinet, D., Kummert, J., Lepoivre, P., and Semal, J. 1994. Identification of distinct potyviruses in mixedly-infected sweetpotato by the polymerase chain reaction with degenerate primers. Phytopathology 84:65-69.

3. Demeke, T., and Adams, R. P. 1992. The effects of plant polysaccharides and buffer additives on PCR. Biotechniques 12:332-334.

4. Devereux, J. J., Haeberli, P., and Smithies, O. 1984. A comprehensive set of sequence analysis programs for the VAX. Nucleic Acids Res. 12:387-395.

5. Howell, W. E., Mink, G. I., Hurtt, S. S., Foster, J. A., and Postman, J. D. 1996. Select Malus clones for rapid detection of apple stem grooving virus. Plant Dis. 80:12001202.
6. Jelkmann, W. 1995. Cherry virus A: cDNA cloning of ds RNA, nucleotide sequence analysis and serology reveal a new plant capillovirus in sweet cherry. J. Gen. Virol. 76:2015-2024.

7. Kinard, G. R., Scott, S. W., and Barnett, O. W. 1996. Detection of apple chlorotic leaf spot and apple stem grooving viruses using RTPCR. Plant Dis. 80:616-621.

8. Kummert, J., Rufflard, G., Colinet, D., and Lepoivre, P. 1995. Detection of apple chlorotic leaf spot virus and apple stem grooving virus by RT-PCR and IC-RT-PCR. Med. Fac. Landbouww. Univ. Gent 60(2a):277287.

9. Langeveld, S. A., Dore, J. M., Memelink, J., Derks, A. F. L. M., Van Der Vlugt, C. I. M., Asjes, C. J., and Bol, J. F. 1991. Identification of potyviruses using the polymerase chain reaction with degenerate primers. J. Gen. Virol. 72:1531-1541.

10. Lister, R. M. 1970. Apple stem grooving virus. C.M.I./A.A.B. Descriptions of Plant Viruses. No. 31. Commonw. Mycol. Inst./Assoc. Appl. Biol., Kew, Eng.

11. MacKenzie, D. J., McLean, M. A., Mukerji, S., and Green, M. 1997. Improved RNA extraction from woody plants for the detection of viral pathogens by reverse transcriptionpolymerase chain reaction. Plant Dis. 81:222226.

12. Magome, H., Yoshikawa, N., Takahashi, T., Ito, T., and Miyakawa, T. 1997. Molecular variability of the genomes of capilloviruses from apple, Japanese pear, European pear, and citrus trees. Phytopathology 87:389-396.

13. Mallet, F., Oriol, G., Mary, C., Verrier, B., and Mandrand, B. 1995. Continuous RT-PCR using AMV-RT and Taq DNA polymerase: Characterization and comparison to uncoupled procedures. BioTechniques 18:678-687.

14. Myers, T. W., and Gelfand, D. H. 1991. Reverse transcription and DNA amplification by a Thermus thermophilus DNA polymerase. Biochemistry 30:7661-7666.

15. Nemeth, M. 1986. Virus, Mycoplasma, and Rickettsia Diseases of Fruit Trees. Kluwer Academic Press, Hingham, MA.

16. Ohira, K., Namba, S., Rozanov, M., Kusumi, T., and Tsuchizaki, T. 1995 Complete sequence of an infectious fulllength cDNA clone of citrus tatter leaf capillovirus: Comparative sequence analysis of capillovirus genomes. J. Gen. Virol. 76:2305-2309

17. Olmos, A., Dasi, M. A., Candresse, T., and Cambra, M. 1996. Print capture PCR: A simple and highly sensitive method for detection of plum pox virus (PPV) in plant tissues. Nucleic Acids Res. 24:2192-2193.

18. Robertson, N. L., French, R., and Gray, S. M. 1991. Use of group-specific primers and the polymerase chain reaction for the detection and identification of luteoviruses. J. Gen. Virol. 72:1473-1477.

19. Rowhani, A., Maningas, M. A., Lile, L. S., Daubert, S. D., and Golino, D. A. 1995. Development of a detection system for viruses of woody plants based on PCR analysis of immobilized virions. Phytopathology 85:347352.

20. Rybicky, E. P., and Hughes, F. L. 1990. Detection and typing of maize streak virus and other distantly related geminiviruses of grasses by polymerase chain reaction amplification of a conserved viral sequence. J. Gen. Virol. 71:2519-2526.

21. Sanger, F., Nicklen, S., and Coulson, A. R. 1977. DNA sequencing with chain terminating inhibitors. Proc. Natl. Acad. Sci. USA 74:5463-5467.

22. Valverde, R. A., Nameth, S. T., and Jordan, R. L. 1990. Analysis of double-stranded RNA 
for plant virus diagnosis. Plant Dis. 74:255258.

23. Welsh, M. F., and van der Meer, F. A. 1989. Apple stem grooving virus. Pages 127-137 in: Virus and Viruslike Diseases of Pome Fruits and Simulating Noninfectious Disorders. Washington State University, Pullman.
24. Wetzel, T., Candresse, T., Macquaire, G., Ravelonandro, M., and Dunez, J. 1992. A highly sensitive immunocapture polymerase chain reaction method for plum pox virus detection. J. Virol. Methods 39:27-37.

25. Wyatt, S. D., and Brown, J. K. 1996. Detection of subgroup III geminivirus isolates in leaf extracts by degenerate primers and polymerase chain reaction. Phytopathology 86:1288-1293.

26. Yoshikawa, N., Sasaki, E., Kato, M., and Takahashi, T. 1992. The nucleotide sequence of apple stem grooving capillovirus genome. Virology 191:98-105. 